GRASAS Y ACEITES 72 (4)

October-December 2021, e429

ISSN-L: 0017-3495

https://doi.org/10.3989/gya.0773201

\title{
Oil quality characterization of the Arauco variety from the main olive growing areas of Mendoza (Argentina)
}

\author{
$\triangle$ A.P. Banco ${ }^{\mathrm{a},} \bowtie$, $\odot$ C.M. Puertas ${ }^{\mathrm{a}}, \oplus E . R$. Trentacoste $^{\mathrm{a}}$ and $₫$ R.P. Monasterio ${ }^{\mathrm{b}, \mathrm{c}}$ \\ ${ }^{a}$ Estación Experimental Agropecuaria Junín (Instituto Nacional de Tecnología Agropecuaria), Isidoro Busquets s/n La colonia, Junín, \\ Mendoza, Argentina. \\ 'Instituto de Biología Agrícola de Mendoza (IBAM), Universidad Nacional de Cuyo (UNCuyo), CONICET, Chacras de Coria, Mendoza, \\ Argentina. \\ 'Departamento de Biomatemática y Físicoquímica, Facultad de Ciencias Agrarias, UNCuyo, Chacras de Coria, Mendoza, Argentina. \\ ${ }^{\otimes}$ Corresponding author: banco.adriana@inta.gob.ar
}

Submitted: 02 July 2020; Accepted: 05 October 2020; Published online: 13 January 2022

\begin{abstract}
SUMMARY: 'Arauco' forms part of the over two thousand olives (Olea europaea L.) varieties identified worldwide with the peculiarity of being the only recognized variety from Argentina. In this work, the fruit and oil characteristics from the 'Arauco' variety cultivated in the three main olive growing zones of Mendoza province (Argentina) were evaluated over two harvests (2016 and 2017). The characteristics assessed were oil and water concentrations, pulp/pit ratio, industrial yield, oxidative stability, fatty acid profile, total phenols and total flavonoids, among others. The results showed relatively high oleic acid and phenolic contents, together with low acidity and extinction coefficients $\left(\mathrm{K}_{232}\right.$ and $\left.\mathrm{K}_{270}\right)$, as well as a well-balanced fatty acid profile. In addition, three interesting relationships among oxidative stability and ratios of monounsaturated fatty acids/polyunsaturated fatty acids $\left(\mathrm{R}^{2}=0.96\right)$, oleic/linoleic $\left(\mathrm{R}^{2}=0.96\right)$ and stearic acid $\left(\mathrm{R}^{2}=0.93\right)$ were observed. These results showed that the 'Arauco' variety cultivated in Mendoza provides excellent oil quality.
\end{abstract}

KEYWORDS: Fatty acid profile; Olea europaea L.; Olive oil; Phenolic content

RESUMEN: Caracterización de la calidad del aceite de la variedad Arauco en las principales áreas productoras de Mendoza (Argentina). 'Arauco' forma parte de las más de dos mil variedades de olivo reconocidas mundialmente, con la particularidad de ser la única variedad reconocida de Argentina. En este trabajo, se evaluaron las características de frutos y aceite de la variedad 'Arauco' cultivada en las tres principales áreas productoras de la provincia de Mendoza (Argentina), durante dos cosechas (2016 y 2017). Las características estudiadas fueron concentración de agua y aceite, relación pulpa/hueso, rendimiento industrial, estabilidad oxidativa, perfil de ácidos grasos, fenoles y flavonoides totales entre otras. Los resultados mostraron un contenido relativamente alto de fenoles y de ácido oleico, sumado a bajos coeficientes de extinción $\left(\mathrm{K}_{232}\right.$ y $\left.\mathrm{K}_{270}\right)$ y acidez, así como un perfil de ácidos grasos bien equilibrado. Además, se observaron tres interesantes relaciones entre estabilidad oxidativa y las relaciones de ácidos grasos monoinsaturados/poliinsaturados $\left(R^{2}=0.96\right)$, oleico/linoleico $\left(\mathrm{R}^{2}=0.96\right)$ y el ácido esteárico $\left(\mathrm{R}^{2}=0.93\right)$. Los resultados mostraron que la variedad 'Arauco' cultivada en Mendoza da aceite de excelente calidad.

PALABRAS CLAVE: Aceite de oliva; Contenido fenólico; Perfil de ácidos grasos; Olea europaea L.

Citation/Cómo citar este artículo: Banco AP, Puertas CM, Trentacoste ER, Monasterio RP. 2021. Oil quality characterization of the Arauco variety in the main olive growing areas of Mendoza (Argentina). Grasas Aceites 72 (4), e429. https://doi.org/10.3989/gya.0773201

Copyright: (C2021 CSIC. This is an open-access article distributed under the terms of the Creative Commons Attribution 4.0 International (CC BY 4.0) License. 


\section{INTRODUCTION}

The olive tree is an ancient species from the Mediterranean region. Evidence of its use dates back to 3000 years before Christ, when Crete already exported olive oil to the Egyptians (Riley, 2002). In the American continent, it was first introduced by colonizers in the fifteenth century, and it was thanks to its plasticity that this crop spread to new environments. Nowadays, only four varieties are recognized in America: 'Arauco' in Argentina, 'Azapa' in Chile, 'Mission' in the United States (Bartolini et al., 1998), and 'Criolla' in Peru (Castillo-Llanque et al., 2008).

In Argentina, the commercial expansion of the olive crop took place after 1850 with the arrival of European immigrants. In 1992, tax exemption laws benefited the northwestern provinces (i.e. Catamarca, La Rioja and San Juan) located between latitude $28^{\circ} \mathrm{S}$ and $31^{\circ} \mathrm{S}$, which widely expanded their olive cultivation surface area (SAGPYA, 2010). Before that law, Mendoza (a southern province located at $32^{\circ} \mathrm{S}$ latitude) was the main olive growing area due to its environmental conditions (i.e. low daily temperatures) (Gómez Del Campo et al., 2010). This, added to other environmental conditions such as low nightly temperatures, high irradiance during fruit maturation and the quality of irrigation water, favored the production of oil of excellent quality. Cornejo et al. (2014), evaluating oil quality of 'Arbequina' from three different regions in the San Juan province $\left(31^{\circ} \mathrm{S}\right)$, observed that high temperatures (above $35^{\circ} \mathrm{C}$ ) affected oleic and linoleic acid composition, and affected the olive oil's shelflife. Similar results were obtained by Rondanini et al. (2011) and Rondanini et al. (2014), who evaluated seventeen varieties from warm valleys of La Rioja province $\left(29^{\circ} \mathrm{S}\right)$. This particular situation entails difficulties in international marketing, because an oil can be suspected of fraud or adulteration for this reason.

In recent years, many studies have been conducted in Argentina to describe the morphologic, agronomic and management characteristics of foreign varieties (Rondanini et al., 2011; Torres and Maestri, 2006; Torres et al., 2017), although little is yet known about the local 'Arauco' variety. For example, some studies describe it as a table olive variety due to its considerable size and high pulp/pit ratio (Fernández et al., 2014; Fernandez et al., 2018). Other studies highlight olive oil from 'Arauco' variety for its well-balanced fatty acid composition (Bodoira et al., 2015) and high phenolic content (Bodoira et al., 2015; Ceci and Carelli, 2007; Monasterio et al., 2017). High phenolic content oils are increasingly interesting due to their nutraceutical quality (Aguilera et al., 2004; Visioli and Galli, 1998) and sensory attributes like bitterness and pungency (Inarejos-García et al., 2013). In addition, among olive oil phenolic compounds, flavonoids are an important group with a key role due to their antioxidant effects (Bouaziz et al., 2005).
Ceci and Carelli (2010) studied olive oils from a wide range of Argentinian zones that showed an increase in the concentration of some fatty acids (mainly oleic acid) and phenol compounds with an increase in latitude. Similar results were found by Rondanini et al. (2014) and Trentacoste et al. (2020). Ceci and Carelli (2010) also detected an increase in the oleic/(linoleic + linolenic) ratio and oxidative stability toward higher southern latitudes (i.e. colder environments). In Mendoza, 'Arauco' has been one of the most cultivated varieties ( $20 \%$ of the total provincial olive crop surface area) mainly grown in the North (Maipú and Lavalle) and East (Junín, Rivadavia and San Martín) of the province. 'Arauco' predominates in olive orchards with trees over fifty years old with traditional management (low density, surface irrigation and manual harvest) (Baroni et al., 2010). The new trend in olive farming toward growing just a few varieties with demonstrated adaptation to high plant density, drip irrigation and mechanization, increases the risk of loss in genetic variability. The 'Arauco' variety has not been selected for new orchards; it has even been superseded by more easily adapted varieties. Precisely for this reason, knowing the characteristics of this variety is becoming progressively more important as its excellent nutraceutical attributes are increasingly appreciated. In this sense, the aims of this work were to: (i) evaluate the fruit characteristics and oil composition of the 'Arauco' variety in the three main olive growing areas of Mendoza (Junín, Rivadavia and Maipú), and (ii) explore the relationship between oil and fruit traits affected by environmental (regional) conditions.

\section{MATERIALS AND METHODS}

\subsection{Zones and plant material}

Assays were carried out over two harvest years (2016 and 2017) on the 'Arauco' variety grown in orchards with similar management and ages, located in three important olive growing areas of the Mendoza province (see maps in Figure 1).

Zone 1 (Junín) is included in the Olive Germplasm Collection of Mendoza, which is situated in the experimental farm of INTA in Junín $\left(33^{\circ} 06^{\prime} \mathrm{S}, 68^{\circ} 29^{\prime} \mathrm{W}, 653\right.$ m.a.s.l). The plantation was established in 1956 . The region has a historical average temperature of $17.3{ }^{\circ} \mathrm{C}$, a rainfall of $275 \mathrm{~mm}$ (mainly in summer and far below olive crop water requirements) and a frost-free period from November to April. Trees from the olive collection are spaced $12 \mathrm{~m} \mathrm{x} 12 \mathrm{~m}$ (traditional system) and fortnightly flood irrigated to replenish the soil water content over the growing seasons.

Zone 2 (Rivadavia) is located within a commercial olive orchard in Los Campamentos, Rivadavia $\left(33^{\circ} 15^{\prime} \mathrm{S}, 68^{\circ} 26^{\prime} \mathrm{W}\right.$, 660 m.a.s.l). The plantation was established in 1980 . The region has a historical average temperature of $18.5^{\circ} \mathrm{C}$, a rain- 

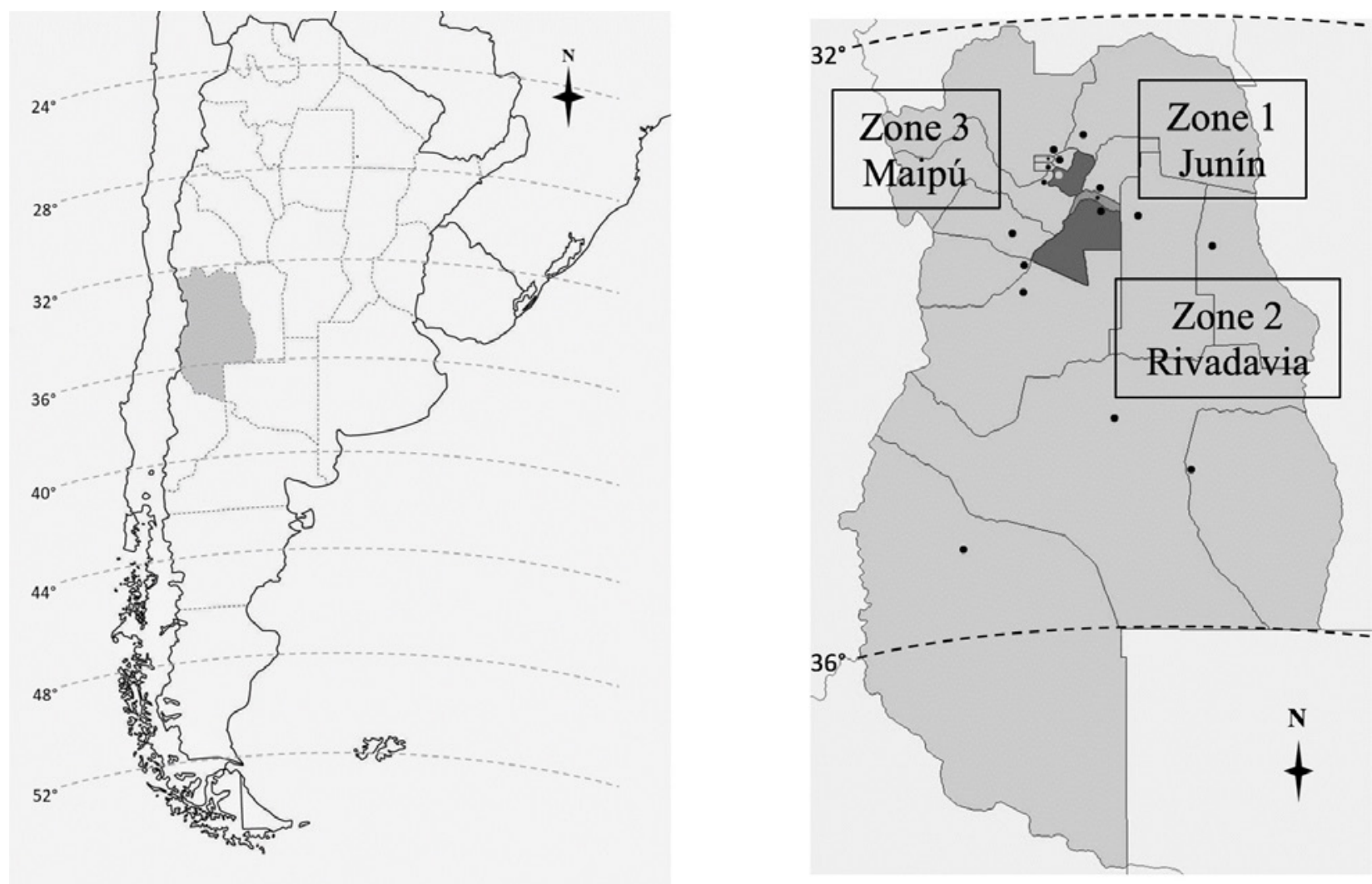

FIGURE 1. Map of Argentina highlighting Mendoza province and map of Mendoza highlighting the main three olive growing zones evaluated.

fall of $195 \mathrm{~mm}$ (mainly in summer) and a frost-free period from November to March. Trees are spaced $10 \mathrm{~m}$ x $10 \mathrm{~m}$ (traditional system) and drip irrigated to replenish the soil water content and thus avoid water deficit.

Zone 3 (Maipú) is situated within a commercial ol-

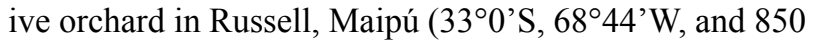
m.a.s.1). The plantation was established in 1986 . The region has a historical average temperature of $19.5^{\circ} \mathrm{C}$, a rainfall of $120.5 \mathrm{~mm}$ (mainly in summer) and a frost-free period from October to April. Trees are spaced $10 \mathrm{~m}$ x 10 $\mathrm{m}$ (traditional system) and flood irrigated to replenish the soil water content and avoid water deficit.

From each orchard, four trees were randomly selected before collecting olives with similar crown volume and high fruit load. Manual harvest was conducted during the first half of May, before frost events. A fruit sample of $20 \mathrm{~kg}$ per tree (replicate) was taken. One replicate was used for machine conditioning and the oil obtained was not considered for the study. From the other three replicates, a fruit subsample of $2 \mathrm{~kg}$ was randomly selected to perform fruit analysis (pulp oil concentration in fresh and dry basis, fruit weight, fruit humidity, pulp/pit ratio and maturity index). The rest of the fruits $(18 \mathrm{~kg})$ were milled to extract olive oil. Briefly, olive fruits were crushed with a hammer mill and the olive paste obtained was malaxated for $40 \mathrm{~min}$ until passing through the decanter (Spremolive New $20 \mathrm{~kg} \cdot \mathrm{h}^{-1}$, Toscana Enologica
Mori) without the addition of water. Afterwards, the olive oil obtained was filtered and stored in a cold and dark place until its analytical parameters were determined.

\subsection{Morphological and chemical characteristics of the fruit}

Fruit dry weight and water concentration were determined in a sample of 100 fruits which were fresh-weighed and oven-dried $\left(60{ }^{\circ} \mathrm{C}\right)$ to a constant weight. Fruit dry weight was also measured. Next, water concentration was calculated from the difference between fresh and dry weight divided by fresh weight. Pulp/pit ratio was determined from a sample of 50 randomly selected and weighed fruits; then, their pits were manually separated and weighed. Another sample of 100 fruits was randomly selected to determine maturity index, according to Uceda and Frías (1975). Industrial yield was calculated by dividing kilograms of olive oil obtained by kilograms of milled fruit and then multiplied by 100 to express it as percentage.

Pulp oil concentration was determined in triplicate according to Avidan et al. (1999). In brief, $5 \mathrm{~g}$ of pulp were weighed and oven-dried $\left(60^{\circ} \mathrm{C}\right)$ to constant weight. Dried-pulp was weighed and crushed in a mortar and transferred to a test tube containing $10 \mathrm{~mL}$ of petroleum ether. After $12 \mathrm{~h}$ of shaking, the samples were filtered, transferred to a new, previously-weighed test tube and 
air-evaporated. Later, samples were oven-dried $\left(60^{\circ} \mathrm{C}\right)$ to constant weight. Pulp oil concentration was calculated on fresh basis (POCfb) and dry basis (POCdb) from weight difference.

\subsection{Analytical methods}

Oil quality was determined through acidity (expressed as oleic acid) and extinction coefficients $\left(\mathrm{K}_{232}\right.$ and $\left.\mathrm{K}_{270}\right)$ according to the International Olive Council (IOC, 2015a, 2015 b). In addition, oil oxidative stability was calculated by measuring oxidation induction time using Rancimat equipment (Metrohm Ltd., Herisau, Switzerland). In summary, a sample of oil ( $3 \mathrm{~g}$ ) was force-oxidized by means of air flow $\left(10 \mathrm{~L} . \mathrm{h}^{-1}\right)$ and heat $\left(110^{\circ} \mathrm{C}\right)$. As a result, the necessary time to reach the curve inflection point was obtained.

Total phenolic content was determined according to the International Olive Council method (IOC, 2017). Briefly, a portion of olive oil ( $2 \mathrm{~g}$ ) was weighed and mixed together with the internal standard syringic acid. Next, it was extracted by an ultrasound bath at room temperature with a mix of methanol/water $(80 / 20 \mathrm{v} / \mathrm{v})$. Afterwards, it was centrifuged and the supernatant was filtered and injected into a liquid chromatograph Dionex Ultimate 3000 HPLC system (CA, USA) with a UV detector at $280 \mathrm{~nm}$. $\mathrm{A} \mathrm{C}_{18}$ reverse-phase column, $\operatorname{Roc}^{\circledR}$ Restek $(250$ x $4.6 \mathrm{~mm}$; $5 \mu \mathrm{m})$ (Pennsylvania, USA) was used, employing a gradient of water $0.2 \%$ phosphoric acid ( $(\mathrm{v} / \mathrm{v}) / \mathrm{methanol} / \mathrm{ace}-$ tonitrile) as indicated by the official methodology.

Total flavonoids were determined by the modified method of Zhishen et al. (1999). A sample of olive oil (6 g) was added to $10 \mathrm{~mL}$ of methanol/water solution $(4: 1$ $\mathrm{v} / \mathrm{v}$ ), the mixture was shaken for $10 \mathrm{~min}$ at $4000 \mathrm{rpm}$, and the supernatant was extracted and put in a flask. This process was repeated three times. In a $10 \mathrm{~mL}$ volumetric flask, $1 \mathrm{~mL}$ of sample was added to $4 \mathrm{~mL}$ of distilled $\mathrm{H}_{2} \mathrm{O}$. Next, $0.3 \mathrm{~mL}$ of sodium nitrite $(5 \% \mathrm{p} / \mathrm{v})$ were added. After $5 \mathrm{~min}, 0.3 \mathrm{~mL}$ of aluminum chloride $(10 \% \mathrm{p} / \mathrm{v})$ were added, and $6 \mathrm{~min}$ later, $2 \mathrm{~mL}$ of sodium hydroxide (1M) were added. The volumetric flask was filled to the mark with distilled water. Flavonoids were measured by spectrophotometry at $510 \mathrm{~nm}$ of absorbance against a blank.

Olive oil fatty acid composition was determined by the IOC method (2001). An oil sample was weighed and dissolved with heptane. Afterwards, it was derivatized with a methanolic potassium hydroxide solution. The solution was left to decant and the supernatant was analyzed with a Shimadzu GC 2010 Plus gas chromatography system (Shimadzu, Japan), using a hydrogen flame ionization detector and a ZB-FAME capillary column (60 m x $0.25 \mathrm{~mm}$; 0.2 um) (Zebron, Phenomenex, USA). Detection and injection were set at $260{ }^{\circ} \mathrm{C}$ and $240{ }^{\circ} \mathrm{C}$, respectively, using hydrogen as carrier gas. The amounts of fatty acids were expressed as relative area percentages and identified by comparing their retention times with those of standard solutions. The fatty acids detected were palmitic (C16:0), palmitoleic (C16:1), margaric (C17:0), margaroleic (C17:1), stearic (C18:0), oleic (C18:1), linoleic (C18:2), linolenic (C18:3), arachidic (C20:0), eicosenoic (C20:1) and behenic (C22:0).

\subsection{Statistical analysis}

Data of zones and harvest years were submitted for variance analysis and means separated using the Tukey-test $(\alpha=0.05)$ and InfoStat statistical software version 1.5 (Di Rienzo et al., 2002). A regression analysis was applied to study the relationships among all the parameters analyzed in both fruits and oil.

\section{RESULTS AND DISCUSSION}

Absolute maximum, absolute minimum and mean temperatures, relative humidity and accumulated rainfall from August to May (i.e. from bud-break to harvest) for the two seasons studied (2015-2016 and 2016-2017), and the three main olive growing zones in Mendoza are shown in Figure 2 and Table 1. Mean temperatures in Zones 1, 2 and 3 were $16.6^{\circ} \mathrm{C}, 17.1^{\circ} \mathrm{C}$ and $17.3^{\circ} \mathrm{C}$, respectively, for the $2015-2016$ season, and $17.9^{\circ} \mathrm{C}, 18.3^{\circ} \mathrm{C}$ and $18.1{ }^{\circ} \mathrm{C}$, respectively, for the 2016-2017 season. The highest temperatures during the fruit development period (i.e. January-May), were $39.6{ }^{\circ} \mathrm{C}$ and $42.0^{\circ} \mathrm{C}$, recorded in January, 2016 and January, 2017 in Zone 2, respectively. While the lowest temperatures recorded were $-2.8{ }^{\circ} \mathrm{C}$ in April, 2016 and $-2.3{ }^{\circ} \mathrm{C}$ in May, 2017, both in Zone 2. Thus, the main difference among zones was thermal amplitude, mainly during the January-May period, which was higher in Zone 2 (average 2015 and $2016=27.9^{\circ} \mathrm{C}$ ), followed by Zones $1\left(26.5^{\circ} \mathrm{C}\right)$ and $3\left(24.5^{\circ} \mathrm{C}\right)$ in an east-west gradient. Accumulated rainfall ranged from the lowest values recorded in Zone 3 (195 and $168 \mathrm{~mm}$ in 2016 and 2017, respectively), intermediate in Zone 1 (425 and 239) to the highest values in Zone 2 (425 and 239, respectively). The 2015-2016 season was wetter than the 2016-2017 season. Orchards were frequently irrigated because the amount of rainfall was far below crop water requirements.

\subsection{Fruit characteristics}

The fruit characteristics of the 'Arauco' variety from the three main olive growing zones of Mendoza for the two seasons are shown in Table 2.

Taking into account zones and crop seasons, fruits from the 'Arauco' variety showed fresh and dry weight of $5.1 \mathrm{~g}$ and $1.8 \mathrm{~g}$, respectively, pulp/pit ratio of 7.8 , water concentration of $64.4 \%$ and oil concentration of $15.8 \%$ and $50.1 \%$ on fresh and dry weight basis, respectively, and a maturity index of 1.5. 'Arauco' has a large size, pulp/pit ratio higher than 5 , and slow change in skin color, 

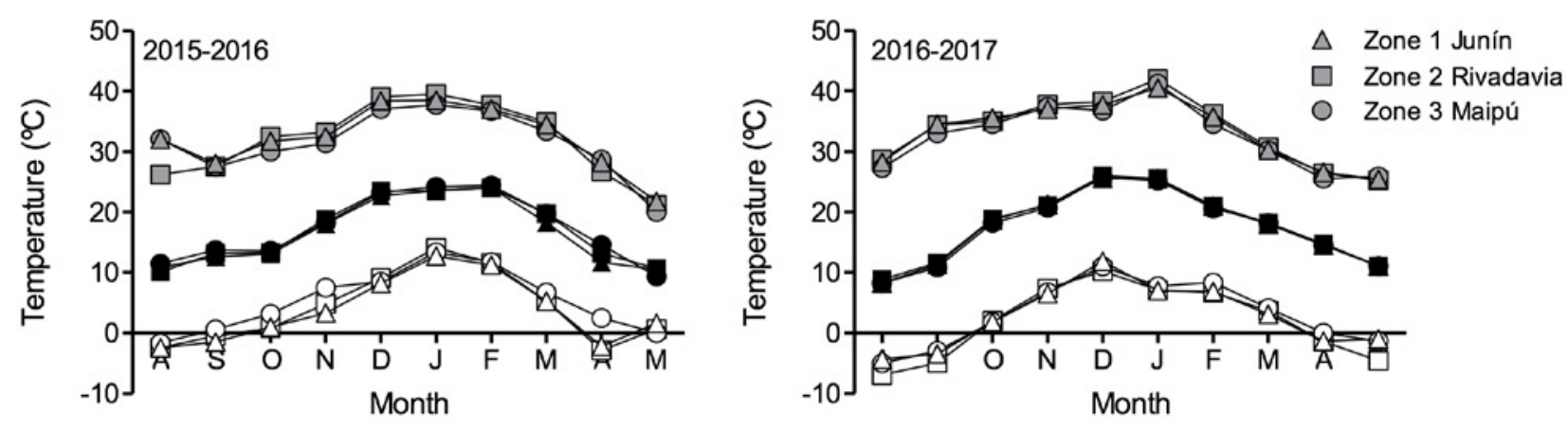

FiguRE 2. Absolute maximum (gray symbols), mean (black symbols) and absolute minimum (white symbols) temperatures from August to May during 2015-2016 and 2016-2017 growing seasons in three olive growing zones of Mendoza, Argentina.

characteristics which are highly appreciated for table olive elaboration (Bodoira et al., 2015; Kailis and Harris, 2007), which constitutes the main industrial use of this variety in Argentina.

Fruit characteristics were significantly different among zones with the exception of pulp oil concentration. Across seasons, the fruits collected from Zone 2 showed higher fresh weight (6.4 g) and dry weight (2.2 g), pulp/ pit ratio (8.9) and were more mature (2.3) than the fruits collected from Zones 1 and 3 (average $4.4 \mathrm{~g}, 1.6 \mathrm{~g}, 7.3$, 1.1 , following the same sequence as Zone 2). The fruit water concentration from Zones 1 and 2 was on average $65.4 \%$ higher than Zone 3 (62.6\%). During oil processing, the oil extraction yield showed a similar pattern, with the highest value in Zone 2, intermediate in Zone 1, and the lowest in Zone 3. The earlier maturation and higher fruit size and pulp/stone ratio observed in Zone 2 seem to be more associated with fruit load and orchard management than with environmental conditions.

In all environments, except Zone $2(\mathrm{MI}=2.3)$, fruits were harvested with a maturity index lower than 1.5 prior to the occurrence of severe early frost, which served to ensure high-quality oil. Bodoira et al. (2015) evaluated the olive variety 'Arauco' in the San Juan province and determined maximum oil concentration at a low maturity index (below 1) and maturity index between 1 and 2 to achieve maximum oil quality. In a previous study carried out in Mendoza on the 'Arauco' variety, it was observed that harvest before mid-May led to obtaining maximum oil quality by reducing olive exposure to severe frost events (Trentacoste et al., 2020). Similarly, Morelló et al. (2003) evaluated the effects of frost on the Arbequina variety oil and determined a significant decrease in phenol content and pigments due to frost.

\subsection{Oil characteristics}

Basic oil quality parameters (phenolic content, oxidative stability, acidity, extinction coefficients) and total
TABLE 1. Total rainfall, relative humidity (RH) and average monthly maximum, mean and minimum temperatures from November to May during 2015-2016 and 2016-2017 growing seasons in the three principal olive zones of Mendoza, Argentina

\begin{tabular}{ccccccc}
\hline Average date* & $\begin{array}{c}\text { Max } \\
\text { temp } \\
\left({ }^{\circ} \mathbf{C}\right)\end{array}$ & $\begin{array}{c}\text { Mean } \\
\text { temp } \\
\left({ }^{\circ} \mathbf{C}\right)\end{array}$ & $\begin{array}{c}\text { Min } \\
\text { temp } \\
\left({ }^{\circ} \mathbf{C}\right)\end{array}$ & $\begin{array}{c}\text { Rainfall } \\
(\mathbf{m m})\end{array}$ & $\begin{array}{c}\text { RH } \\
(\%)\end{array}$ \\
\hline \multirow{2}{*}{2016} & Zone 1 & 33.0 & 18.4 & 5.8 & 425.0 & 69.8 \\
& Zone 2 & 33.2 & 19.1 & 6.1 & 514.4 & 60.4 \\
& Zone 3 & 32.2 & 19.1 & 7.2 & 194.6 & 61.7 \\
& Zone 1 & 34.6 & 19.7 & 6.2 & 239.2 & 59.5 \\
& Zone 2 & 35.9 & 20.1 & 5.1 & 382.6 & 50.5 \\
& Zone 3 & 33.9 & 20.1 & 7.1 & 168.4 & 51.1 \\
\hline
\end{tabular}

*Nov/May average dates (2015-2016 and 2016-2017).

TABLE 2. Fruit characteristics (mean \pm standard deviation, $n=6$ ) from 'Arauco' variety evaluated during two harvests (2016 and 2017) in the three main olive zones of Mendoza, Argentina

\begin{tabular}{lccc}
\hline Variable & Zone 1 & Zone 2 & Zone 3 \\
\hline POCfb (\%) & $14.3 \pm 1.3$ & $14.7 \pm 1.0$ & $18.4 \pm 5.1$ \\
POCdb (\%) & $50.5 \pm 1.7$ & $49.7 \pm 1.2$ & $50.3 \pm 4.9$ \\
MI & $1.1 \pm 0.4 \mathrm{~b}$ & $2.3 \pm 0.6 \mathrm{a}$ & $1.2 \pm 0.2 \mathrm{~b}$ \\
FFW (g·100 fruits $\left.^{-1}\right)$ & $474.8 \pm 87.0 \mathrm{~b}$ & $645.5 \pm 51.1 \mathrm{a}$ & $407.7 \pm 28.4 \mathrm{~b}$ \\
FDW (g·100 fruits $\left.^{-1}\right)$ & $164.7 \pm 27.9 \mathrm{~b}$ & $222.7 \pm 25.7 \mathrm{a}$ & $152.3 \pm 7.3 \mathrm{~b}$ \\
P/P & $7.9 \pm 1.1 \mathrm{~b}$ & $8.9 \pm 0.4 \mathrm{a}$ & $6.6 \pm 0.5 \mathrm{c}$ \\
IY (\%) & $4.9 \pm 1.1 \mathrm{~b}$ & $6.6 \pm 1.8 \mathrm{a}$ & $3.4 \pm 0.7 \mathrm{c}$ \\
WC (\%) & $65.2 \pm 2.4 \mathrm{a}$ & $65.6 \pm 1.4 \mathrm{a}$ & $62.6 \pm 1.8 \mathrm{~b}$ \\
\hline
\end{tabular}

POCfb: pulp oil concentration on fresh basis, POCdb: pulp oil concentration in dry basis, MI: maturity index, FFW: fruit fresh weight, FDW: fruit dry weight, P/P: pulp/pit ratio, IY: industrial yield, WC: water concentration. Significant differences in the same row are shown by different letters $(\mathrm{p}<0.05)$. Tukey test $(\mathrm{p}<0.05)$ was used for comparison of means 
TABLE 3. Oil characteristics (mean \pm standard deviation, $n=6$ ) from 'Arauco' variety evaluated during two harvests (2016 and 2017) in the three main olive zones of Mendoza, Argentina

\begin{tabular}{|c|c|c|c|}
\hline Variable & Zone 1 & Zone 2 & Zone 3 \\
\hline Acidity $\leq 0.8 \%$ oleic acid $*$ & $0.19 \pm 0.1$ & $0.17 \pm 0.0$ & $0.20 \pm 0.1$ \\
\hline $\mathrm{K} 232 \leq 2.50^{*}$ & $1.05 \pm 0.6 \mathrm{~b}$ & $1.15 \pm 0.7 \mathrm{a}$ & $0.91 \pm 0.8 \mathrm{c}$ \\
\hline $\mathrm{K} 270 \leq 0.22 *$ & $0.09 \pm 0.0$ & $0.09 \pm 0.0$ & $0.10 \pm 0.0$ \\
\hline Oxidative stability (h) & $8.5 \pm 1.4 \mathrm{~b}$ & $7.8 \pm 0.3 b$ & $10.4 \pm 0.8 \mathrm{a}$ \\
\hline Total phenol content $\left(\mathrm{mg} \cdot \mathrm{kg}^{-1}\right)$ & $401.7 \pm 63.1$ & $438.8 \pm 59.4$ & $462.2 \pm 70.3$ \\
\hline Total flavonoid content $\left(\mathrm{mg} \cdot \mathrm{kg}^{-1}\right)$ & $50.2 \pm 25.3$ & $61.5 \pm 17.1$ & $49.9 \pm 35.3$ \\
\hline \multicolumn{4}{|l|}{ Fatty acids } \\
\hline Palmitic acid (C16:0) $7.50-20.0 \% *$ & $16.2 \pm 2.7 \mathrm{~b}$ & $18.1 \pm 0.9 \mathrm{a}$ & $14.6 \pm 1.1 \mathrm{c}$ \\
\hline Palmitoleic acid (C16:1) $0.3-3.5 \% *$ & $1.5 \pm 0.4 \mathrm{~b}$ & $2.2 \pm 0.2 \mathrm{a}$ & $1.1 \pm 0.2 \mathrm{c}$ \\
\hline Margaric acid $(\mathrm{C} 17: 0) \leq 0.4 \%^{*}$ & $0.1 \pm 0.1 \mathrm{ab}$ & $0.1 \pm 0.0 \mathrm{a}$ & nd \\
\hline Margaroleic acid $(\mathrm{C} 17: 1) \leq 0.6 \% *$ & $0.1 \pm 0.1$ & $0.1 \pm 0.0$ & $0.1 \pm 0.0$ \\
\hline Stearic acid (C18:0) $0.5-5.0 \% *$ & $2.3 \pm 0.1 b$ & $2.3 \pm 0.1 b$ & $2.7 \pm 0.1 \mathrm{a}$ \\
\hline Oleic acid (C18:1) $55.0-83.0 \% *$ & $65.6 \pm 5.7 \mathrm{~b}$ & $59.1 \pm 1.3 \mathrm{c}$ & $71.7 \pm 0.5 \mathrm{a}$ \\
\hline Linoleic acid (C18:2) 2,5 - 21,0\%* & $12.2 \pm 2.7 \mathrm{~b}$ & $16.2 \pm 0.8 \mathrm{a}$ & $8.0 \pm 0.4 \mathrm{c}$ \\
\hline Arachidonic acid $(\mathrm{C} 20: 0) \leq 0.6 \% *$ & $0.5 \pm 0.1$ & $0.5 \pm 0.1$ & $0.4 \pm 0.2$ \\
\hline Linolenic acid $(\mathrm{C} 18: 3) \leq 1.0 \% *$ & $1.0 \pm 0.1$ & $1.0 \pm 0.3$ & $0.9 \pm 0.1$ \\
\hline Eicosenoic acid $(\mathrm{C} 20: 1) \leq 0.5 \% *$ & $0.3 \pm 0.1$ & $0.3 \pm 0.0$ & $0.3 \pm 0.1$ \\
\hline Behenic acid $(\mathrm{C} 22: 0) \leq 0.2 \% *$ & $0.2 \pm 0.1$ & $0.2 \pm 0.0$ & $0.2 \pm 0.0$ \\
\hline MUFA / PUFA & $5.4 \pm 1.5 \mathrm{~b}$ & $3.6 \pm 0.2 \mathrm{c}$ & $8.2 \pm 0.3 \mathrm{a}$ \\
\hline Oleic / linoleic & $5.7 \pm 1.7 \mathrm{~b}$ & $3.7 \pm 0.3 \mathrm{c}$ & $9.0 \pm 0.4 \mathrm{a}$ \\
\hline UFA / SFA & $4.3 \pm 0.7 \mathrm{a}$ & $3.7 \pm 0.2 b$ & $4.6 \pm 0.2 \mathrm{a}$ \\
\hline
\end{tabular}

*Limit according to the IOC standards for extra virgin olive oil. Significant differences in the same row are shown by different letters $(p<0.05)$. Tukey test $(\mathrm{p}<0.05)$ was used for comparison of means. K232 and K270: Extinction coefficients measured at 232 and $270 \mathrm{~nm}$. MUFA/PUFA: monounsaturated fatty acids/polyunsaturated fatty acids. UFA/SFA: unsaturated fatty acids/saturated fatty acids. nd: not detected

flavonoids are shown in Table 3. All measured samples were classified as extra virgin olive oil according to IOC, 2015a; IOC, 2015b; IOC, 2017. On average, the 'Arauco' variety presented $0.18 \%$ acidity, 0.09 extinction coefficients $\mathrm{K}_{270}, 434 \mathrm{mg} \cdot \mathrm{kg}^{-1}$ phenolic content and $54 \mathrm{mg} \cdot \mathrm{kg}^{-1}$ total flavonoids with non-significant differences among zones, in contrast to oxidative stability $(8.9 \mathrm{~h})$ and extinction coefficient $\mathrm{K}_{232}$ (1.04). The oil from Zone 3 showed the highest oxidative stability $(10.4 \mathrm{~h})$, and the oil from Zone 2 the highest extinction coefficient $\left(\mathrm{K}_{232}=1.2\right)$.

It is worth noting that the phenol content in 'Arauco' oil was above $400 \mathrm{mg} \cdot \mathrm{kg}^{-1}$, regardless of zone. According to Montedoro et al. (1992), 'Arauco' oil could be classified as a variety within the "medium" category (i.e. 200$500 \mathrm{mg} \cdot \mathrm{kg}^{-1}$ ) in relation to phenolic content. The phenolic content range observed here coincides with Monasterio et al. (2017), who evaluated oil from eight olive varieties from Mendoza province, including 'Arauco'. The authors determined the phenolic content in 'Arauco' oil to be within the range of 233 to $404 \mathrm{mg} \cdot \mathrm{kg}^{-1}$. In addition, the phenolic content in the oil from 'Arauco' olives grown in
Mendoza was similar to that of 'Arauco' oil from San Juan $\left(433 \mathrm{mg} \cdot \mathrm{kg}^{-1}\right)\left(33^{\circ} \mathrm{S}\right.$, Bodoira et al., 2015) and higher than that from La Rioja province $\left(166 \mathrm{mg} \cdot \mathrm{kg}^{-1}\right)\left(28^{\circ} \mathrm{S}\right.$, Ceci and Carelli, 2010). These results reveal a possible latitudinal gradient where phenols increase with increasing latitude in the Southern hemisphere in relation to a decrease in temperature (Mousa et al., 1996), which is greater than the thermal gradient observed among the zones studied.

The fatty acid composition of olive oils from the three main growing zones of Mendoza during the two seasons is shown in Table 3. All samples were within IOC legal limits. On average across zones and seasons, the 'Arauco' variety presented the following fatty acid profile: $16.29 \pm 2.25 \%$ palmitic acid, $1.59 \pm 0.54 \%$ palmitoleic acid, $0.04 \pm 0.01 \%$ margaric acid, $0.09 \pm 0.01 \%$ margaroleic acid, $2.42 \pm 0.22 \%$ stearic acid, $65.47 \pm 6.15 \%$ oleic acid, $12.13 \pm 3.74 \%$ linoleic acid, $0.49 \pm 0.11 \%$ arachidonic acid, $0.98 \pm 0.18 \%$ linolenic acid, $0.3 \pm 0.05 \%$ eicosenoic acid, and $0.18 \pm 0.02 \%$ behenic acid. The contents in palmitic, palmitoleic, margaric, stearic, oleic and linoleic acids were significantly different among zones. Conversely, the 
contents in margaroleic acid, arachidonic acid, linolenic acid, eicosenoic acid and behenic acid were not significantly different among zones.

The oil from Zone 2 presented the highest contents in palmitic, palmitoleic, margaric and linoleic acids, and the lowest oleic and stearic acids contents. (the latter not significantly different from Zone 1) with respect to oils from Zones 1 and 3. Maximum temperature during fruit development would partially explain the lower oleic acid content in Zone 2 and a reverse trend for palmitic and linoleic acids. García-Inza et al. (2014) carried out a manipulation experiment over the fruit-growth period in which fruits were exposed to increments of $5{ }^{\circ} \mathrm{C}$ and $10{ }^{\circ} \mathrm{C}$ above ambient temperature. The authors observed that the contents in palmitic and linoleic acids in oil increased linearly with fruit temperature, while oleic acid content decreased. In addition, greater fruit maturity from Zone 2 could contribute to explaining the fatty acid pattern. Gómez del Campo and García (2012) found that more mature fruits produced oil with lower oleic acid content; while the polyunsaturated fatty acid percentage was greater than in less mature fruits.

In the 'Arauco' oils studied, the oleic acid content was higher than $57 \%$, above the IOC limit (55\%). The oleic acid content in oil from 'Arauco' olives grown in Mendoza was similar to the oleic acid range observed in 'Arauco' oil from San Juan $\left(33^{\circ} \mathrm{S}\right.$, Bodoira et al., 2015) and higher than the 53.7-54.3\% obtained in La Rioja and Catamarca provinces $\left(28^{\circ} \mathrm{S}\right.$, Ceci and Carelli, 2007; Rondanini et al., 2011). For the same variety, pooled results reveal a possible latitudinal gradient where oleic acid content increases with increasing latitude in the Southern hemisphere in relation to a decrease in temperature, as previously described by Rondanini et al. (2011).

The main monounsaturated fatty acid was oleic, which ranged from 59.1 to $71.7 \%$; the main saturated fatty acid was palmitic, ranging from 14.6 to $18.1 \%$; and the main polyunsaturated fatty acid was linoleic, which ranged from 8.0 to $16.2 \%$. Together, they accounted for 93.4 to $94.3 \%$ of the fatty acid content. Monounsaturated fatty acid/polyunsaturated fatty acid (MUFA/PUFA), oleic/ linoleic acid, and unsaturated/saturated fatty acid (UFA/ SFA) ratios were calculated (Table 3). On average, the 'Arauco' variety showed the following values for the three zones and two seasons: MUFA/PUFA $=5.6$, oleic/linoleic $=5.9$, and UFA $/ \mathrm{SFA}=4.2$. These values were lower than those around 4.4 which were observed for the same ratios estimated in previous studies on the Arbequina olive variety in Junín (Zone 1) Mendoza, (Lémole et al., 2018). In addition, Zone 3 presented the highest MUFA/PUFA and oleic/linoleic ratios, which were significantly different from the other zones; while the UFA/SFA ratio was similar in both Zones 1 and 3 and significantly higher than in Zone 2.
In addition, linear regressions were studied among all the oil traits analyzed. Some interesting relations were identified between oxidative stability (OS) and fatty acids, or their ratios. Thus, a positive and closer relationship was found between the OS and MUFA/PUFA ratio $\left(\mathrm{R}^{2}=0.96\right)$, than between the OS and UFA/SFA ratio $\left(\mathrm{R}^{2}=0.66\right)$. Bhatnagar et al. (2009) determined that OS is negatively related to PUFA. Our results showed that the induction time to oxidation in 'Arauco' oils was more related to monounsaturated fatty acids than to total phenolic and total flavonoid compounds. This could be explained by the fact that all the samples showed similarly high phenolic contents. Given that the highest content in monounsaturated and polyunsaturated acids in olive oils is due to oleic and linoleic acids, respectively, OS was positively related to the oleic/ linoleic ratio $\left(\mathrm{R}^{2}=0.96\right)$. Nevertheless, not every monounsaturated acid plays such an important role given that palmitoleic acid (C16:1) displayed negative relationships with OS $\left(\mathrm{R}^{2}=0.79\right)$. Other negative relationships were found between OS and linoleic and palmitic acids $\left(\mathrm{R}^{2}=0.90\right.$ and $\mathrm{R}^{2}=0.72$, respectively). Martínez et al. (2014) determined that linoleic acid is highly susceptible to oxidation due to its key role in the lipoxygenase pathway as the precursor of many volatile compounds. In addition, stearic acid (C18:0) showed a positive relationship with $\mathrm{OS}\left(\mathrm{R}^{2}=0.93\right)$. Bhatnagar et al. (2009) evaluated blends with coconut oil, and observed that an increase in saturated fatty acids improved their oxidative stability.

\section{CONCLUSION}

The results of the present study highlight the excellent characteristics of the 'Arauco' variety grown in Mendoza from a nutritional viewpoint in terms of oil quality. The data obtained were not affected by abnormal weather conditions. Environmental variability was slight; therefore, other factors such as fruit load could have contributed to the differences obtained in fruits and oils. However, the total variability in the parameters evaluated was within IOC legal limits. 'Arauco' olive oil from Mendoza presented high oleic acid contents, which was positively correlated with oxidative stability rather than total phenolic and flavonoid contents. MUFA/ PUFA and oleic/linoleic ratios and stearic acid were also positively correlated with oxidative stability. In addition, 'Arauco' showed high fruit fresh weight and high pulp/pit ratio, which explains its extensive use as a double-purpose variety.

\section{ACKNOWLEDGMENTS}

The authors gratefully acknowledge María del Carmen González, Vanesa Lucero, Octavio Contreras and Walter Galarza for their technical assistance. The authors are also grateful for the funds provided by INTA and SIIP-UNCuyo (2019, A102) and to the commercial orchards for allowing access to their olive orchards. 


\section{REFERENCES}

Aguilera CM, Mesa MD, Ramirez-Tortosa MC, Nestares MT, Ros E, Gil A. 2004. Sunflower oil does not protect against LDL oxidation as virgin olive oil does in patients with peripheral vascular disease. Clin. Nutr. 23, 673-681. https://doi.org/10.1016/j.clnu.2003.11.005

Avidan B, Ogrodovitch A, Lavee S. 1999. A reliable and rapid shaking extraction system for determination of the oil content in olive fruit. Acta Hortic. 474, 653-658. https://doi.org/10.17660/ActaHortic.1999.474.135

Baroni A, Fernández C, Ríos-Vera M, Pérez-Andreuccetti C, Fernández L, Alegre F, Cantaloube M. 2010. Censo Frutícola Provincial 2010.

Bartolini G, Prevost G, Messeri C, Carignani G, Menini UG. 1998. Olive germplasm: cultivars and worldwide collections. FAO. Rome, Italy.

Bhatnagar AS, Prasanth Kumar PK, Hemavathy J, Gopala Krishna AG. 2009. Fatty Acid Composition, Oxidative Stability, and Radical Scavenging Activity of Vegetable Oil Blends with Coconut Oil. J. Am. Oil Chem. Soc. 86, 991-999. https://doi.org/10.1007/s11746-009-1435-y

Bodoira R, Torres M, Pierantozzi P, Taticchi A, Servili M, Maestri D. 2015. Oil biogenesis and antioxidant compounds from "Arauco" olive (Olea europaea L.) cultivar during fruit development and ripening: Oil biogenesis from "Arauco" olive cultivar. Eur. J. Lipid Sci. Technol. 117, 377-388. https://doi.org/10.1002/ ejlt.201400234

Bouaziz M, Grayer RJ, Simmonds MSJ, Damak M, Sayadi S. 2005. Identification and Antioxidant Potential of Flavonoids and Low Molecular Weight Phenols in Olive Cultivar Chemlali Growing in Tunisia. $J$. $A g$ ric. Food Chem. 53, 236-241. https://doi.org/10.1021/ jf048859d

Castillo-Llanque FFJ, Casilla EM, Baumann H. 2008. Effect of cross-pollination in "Criolla" olives: A typical cultivar of Peru. Acta Hortic. 275-278. https://doi. org/10.17660/ActaHortic.2008.791.39

Ceci LN, Carelli AA. 2010. Relation Between Oxidative Stability and Composition in Argentinian Olive Oils. J. Am. Oil Chem. Soc. 87, 1189-1197. https://doi. org/10.1007/s11746-010-1598-6

Ceci LN, Carelli AA. 2007. Characterization of Monovarietal Argentinian Olive Oils from New Productive Zones. J. Am. Oil Chem. Soc. 84, 1125-1136. https:// doi.org/10.1007/s11746-007-1140-7

Cornejo V, Bueno LA, Gines IL. 2014. Evaluation of "Arbequina" olive oils from different growing areas of San Juan, Argentina. Acta Hortic. 661-667. https:// doi.org/10.17660/ActaHortic.2014.1057.84

Di Rienzo JA, Guzman AW, Casanoves F. 2002. A multiple-comparisons method based on the distribution of the root node distance of a binary tree. $J$.
Agric. Biol. Environ. Stat. 7, 129-142. https://doi. org/10.1198/10857110260141193

Fernández FJ, Ladux JL, Hammami SBM, Rapoport HF, Searles PS. 2018. Fruit, mesocarp, and endocarp responses to crop load and to different estimates of source: sink ratio in olive (cv. Arauco) at final harvest. Sci. Hortic. 234, 49-57. https://doi.org/10.1016/j.scienta.2018.02.016

Fernández FJ, Ladux JL, Hammami SBM, Rapoport HF, Searles PS. 2014. Fruit and tissue responses of "Arauco" olive fruits to crop load in arid Argentina. Acta Hortic. 89-94. https://doi.org/10.17660/ActaHortic.2014.1057.8

García-Inza GP, Castro DN, Hall AJ, Rousseaux MC. 2014. Responses to temperature of fruit dry weight, oil concentration, and oil fatty acid composition in olive (Olea europaea L. var. 'Arauco'). Eur. J. Agron. 54, 107-115. https://doi.org/10.1016/j.eja.2013.12.005

Gómez Del Campo M, Morales-Sillero A, Vita Serman F, Rousseaux MC, Searles PS. 2010. El olivar en los valles áridos del Noroeste Argentina (provincias de Catamarca, La Rioja y San Juan). OLIVAE 14, 23-45.

Gómez-del-Campo M, García JM. 2012. Canopy Fruit Location Can Affect Olive Oil Quality in 'Arbequina' Hedgerow Orchards. J. Am. Oil Chem. Soc. 89, 123-133. https://doi.org/10.1007/s11746-011-1900-2

Inarejos-García AM, Gómez-Alonso S, Fregapane G, Salvador MD. 2013. Evaluation of minor components, sensory characteristics and quality of virgin olive oil by near infrared (NIR) spectroscopy. Food Res. Int. 50, 250-258. https://doi.org/10.1016/j.foodres.2012.10.029

IOC, 2017. Determination of Biophenols in Olive Oils by HPLC, in COI/T20/Doc N²9/Rev1.

IOC, 2015a. IOC, International Olive Council. Determination of free fatty acids, cold method, in COI/T20/ Doc No 34, Ed.

IOC, 2015b. Spectrphotometric investigation in the ultraviolet, in COI/T20/Doc No 19/Rev 3.

IOC, 2001. Preparation of the fatty acid methyl esteres from olive oil and olive-pomace oil, in COI/T20/Doc $\mathrm{N}^{\circ} 24$.

Kailis S, Harris D. 2007. Producing table olives. Landlinks Press, Collingwood VIC 3066 Australia. https:// doi.org/10.1071/9780643094383

Lémole G, Weibel AM, Trentacoste ER. 2018. Effect of shading in different periods from flowering to maturity on the fatty acid and phenolic composition of olive oil (cv. Arbequina). Sci. Hortic. 240, 162-169. https:// doi.org/10.1016/j.scienta.2018.06.005

Martínez M, Fuentes M, Franco N, Sánchez J, de Miguel C. 2014. Fatty Acid Profiles of Virgin Olive Oils from the Five Olive-Growing Zones of Extremadura (Spain). J. Am. Oil Chem. Soc. 91, 1921-1929. https:// doi.org/10.1007/s11746-014-2528-9 
Monasterio RP, Olmo-García L, Bajoub A, Fernández-Gutiérrez A, Carrasco-Pancorbo A. 2017. Phenolic Compounds Profiling of Virgin Olive Oils from Different Varieties Cultivated in Mendoza, Argentina, by Using Liquid Chromatography-Mass Spectrometry. J. Agric. Food Chem. 65, 8184-8195. https://doi. org/10.1021/acs.jafc. 7b02664

Montedoro G, Servili M, Baldioli M, Miniati E. 1992. Simple and hydrolyzable phenolic compounds in virgin olive oil. 1. Their extraction, separation, and quantitative and semiquantitative evaluation by HPLC. J. Agric. Food Chem. 40, 1571-1576. https://doi. org/10.1021/jf00021a019

Morelló J-R, Motilva M-J, Ramo T, Romero M-P. 2003. Effect of freeze injuries in olive fruit on virgin olive oil composition. Food Chem. 81, 547-553. https://doi. org/10.1016/S0308-8146(02)00488-0

Mousa YM, Gerasopoulos D, Metzidakis I, Kiritsakis A. 1996. Effect of Altitude on Fruit and Oil Quality Characteristics of 'Mastoides' Olives. J. Sci. Food Agric. 71, 345-350. https://doi.org/10.1002/(SICI)10970010(199607)71:3<345::AID-JSFA590>3.0.CO;2-T

Riley FR. 2002. Olive oil production on bronze age Crete: nutritional properties, processing methods and storage life of Minoan olive oil. Oxf. J. Archaeol. 21, 63-75. https://doi.org/10.1111/1468-0092.00149

Rondanini DP, Castro DN, Searles PS, Rousseaux MC. 2014. Contrasting patterns of fatty acid composition and oil accumulation during fruit growth in several olive varieties and locations in a non-Mediterranean region. Eur. J. Agron. 52, 237-246. http://dx.doi. org/10.1016/j.eja.2013.09.002

Rondanini DP, Castro DN, Searles PS, Rousseaux MC. 2011. Fatty acid profiles of varietal virgin olive oils
(Olea europaea L.) from mature orchards in warm arid valleys of Northwestern Argentina (La Rioja). Grasas Aceites 62, 399-409. https://doi.org/10.3989/ gya. 125110

SAGPYA, Secretaría de Agricultura, Ganadería, Pesca y Alimentos, 2010. Cadenas Alimentarias: Producción Olivícola.

Torres MM, Maestri DM. 2006. The effects of genotype and extraction methods on chemical composition of virgin olive oils from Traslasierra Valley (Córdoba, Argentina). Food Chem. 96, 507-511. https://doi. org/10.1016/j.foodchem.2005.03.003

Torres MM, Pierantozzi P, Searles PS, Rousseaux MC, García-Inza G, Miserere A, Bodoira R, Contreras C, Maestri D. 2017. Olive Cultivation in the Southern Hemisphere: Flowering, Water Requirements and Oil Quality Responses to New Crop Environments. Plant Sci. 8, 1830. https://doi.org/10.3389/fpls.2017.01830

Trentacoste ER, Banco AP, Piccoli PN, Monasterio RP. 2020. Olive oil characterization of cv. 'Arauco' harvested at different times in areas with early frost in Mendoza, Argentina. J. Sci. Food Agric. 100, 953960. https://doi.org/10.1002/jsfa.10029

Uceda M, Frias L. 1975. Épocas de recolección. Evolución del contenido graso del fruto y de la composición y calidad del aceite. II Semin. Oleíc. Int. Córdoba Esp. 25-46.

Visioli F, Galli C. 1998. Olive Oil Phenols and Their Potential Effects on Human Health. J. Agric. Food Chem. 46, 4292-4296. https://doi.org/10.1021/jf980049c

Zhishen J. 1999. The determination of flavonoid contentes in mulberry and their scavenging effects on superoxide radicals. Food Chem. 64, 555-559. https:// doi.org/10.1016/S0308-8146(98)00102-2 